\title{
Effects of Aminoethoxyvinylglycine, Chitosan, and Storage Temperatures on Fruit Shelf-Life and Qualities of 'Cavendish' Banana
}

\author{
Zulferiyenni $^{1}$, Soesiladi E. Widodo ${ }^{2}$, Alpenda Putri ${ }^{2}$
}

\begin{abstract}
Cavendish' banana is marketed domestically on its early ripening stage after receiving ethylene gassing. Once its ripening is promoted, however, its fruit qualities are quickly deteriorated making its shelf-life very short. This research was conducted to study the effects of applications of aminoethoxyvinylglycine (AVG), chitosan, storage temperatures, and their interactions on the fruit shelf-life and quality of 'Cavendish' banana. This research was conducted in the Horticultural Postharvest Laboratory, Faculty of Agriculture, Lampung University from July to August 2014. Treatments were arranged in a completely randomized design, run in three replications, and laid out in a $2 \times 2 \times 2$ factorial design. The first factor was AVG (with and without $1.25 \mathrm{ppm}$ AVG), the second factor was chitosan (with and without $2.5 \%$ chitosan), and the third factor was storage temperature (a room temperature and $18{ }^{\circ} \mathrm{C}$ ). The results showed that (1) AVG did not significantly affect fruit shelflife, physical and chemical fruit qualities such as fruit firmness, weight loss, soluble solid and acid contents, and sweetness; (2) $2.5 \%$ chitosan increased fruit shelf-life, but it accelerated fruit softening and increased fruit weight loss, and did not affect chemical fruit qualities; (3) lower storage temperature significantly lengthened fruit shelf-life and inhibited fruit softening, but did not affect physical and chemical fruit qualities; (4) no interaction was found among the three treatments, in fact, a significant effect of an individual application of chitosan or lower storage temperature dominated the effects of its combinations.
\end{abstract}

Keywords - avg, banana, chitosan, postharvest, temperature.

\section{INTRODUCTION}

As 'Cavendish' banana may be the only banana cultivar that is traded worldwide, it has a high economic value. It is a climacteric fruit that is expected to ripe and increase its palatability during storing periode. However, different from most other climacteric fruits, when its fruit is harvested in the stadium I (green rind), its fruit remains green in vacuum polyethylene bags inside cartoon packs during transportation and its qualities are maintained as long as its ripening is not promoted with ethylene gassing and its fruit weight loss and shrunken or wilted rind are avoided. Once its ripening is promoted and reached stadium III and the fruits are started to be distributed locally, brown spots are very quickly developed

\footnotetext{
${ }^{1}$ Agroindustrial Laboratory, Department of Agricultural Product Technology, Faculty of Agriculture, University of Lampung, Bandar Lampung, Indonesia 35145; Email: zulferiyenni@ gmail.com

${ }^{2}$ Horticultural Postharvest Laboratory, Department of Agrotechnology, Faculty of Agriculture, University of Lampung, Bandar Lampung, Indonesia 35145; Email: sestiwidodo@gmail.com
}

on its yellow rind and the fruits are quickly soften or its flesh firmness is quickly decreased in 3-4 days periode. The fruits are said to reach the end of the ripening stage of stage VII, a fruit stage of the end of economical values. Consequently, its postharvest handling problems are not laid before its fruits are promoted with ethylene [1] and [2], but after it, and therefore, retarding this quick fruit deterioration has an economical benefit.

Based on the research conducted by [3] and [4], it was suggested that any attempts to retard banana fruit ripening should be addressed at stage $\mathrm{V}$ (perfectly yellow with green tip and greenish-yellow peduncle) because application to earlier ripening stadium would result in an imperfect fruit color development [3] and [4].

Aminoethoxyvinylglycine (AVG) is believed as the most potent chemical among anti-ethylene substances, because it directly inhibits ACC synthesis activity mechanism [5] and [6]. By applying AVG to inhibit ethylene synthesis, in combination with the fruit coating of chitosan to decrease respiration and transpiration rates [7], [8], and [9] and a low storage temperature, delaying fruit deterioration are expected, and therefore, lengthening the fruit shelf-life and maintaining qualities of 'Cavendish' banana can be achieved.

This research was conducted to study the effects of applications of aminoethoxyvinylglycine (AVG), chitosan, storage temperatures, and their interactions on the fruit shelflife and quality of 'Cavendish' banana.

\section{MATERIALS AND METHODS}

This research was conducted on September-October 2014 in the Horticultural Postharvest Laboratory, Department of Agrotechnology, Faculty of Agriculture, University of Lampung, Bandar Lampung, Indonesia. The samples of 'Cavendish' banana fruit of stages V (perfectly yellow with green tip and greenish-yellow peduncle; [3] and [4]) were received directly from Nusantara Tropical Farm, Co. Ltd. (NTF, Co. Ltd.), Way Jepara, East Lampung, Indonesia.

Treatments were arranged in a completely randomized design with three replications and laid out in a $2 \times 2 \times 2$ factorial design. The replications were applied to each experimental unit consisting of one cluster fruit of two fingers each. The first factor was AVG (with and without $1.25 \mathrm{ppm}$ AVG, by dipping in 10 minutes), the second factor was chitosan (with and without a quick dip in $2.5 \%$ chitosan), and the third factor was storage temperature (a room temperature 
and $\left.18{ }^{\circ} \mathrm{C}\right)$. The chitosan was diluted in $0.5 \%$ acetic acid [3], [4], [10], and [11].

Treated fruits were then placed in storage rooms of a room temperature of $28 \pm 1{ }^{\circ} \mathrm{C}$ and a low temperature of $18 \pm 1^{\circ} \mathrm{C}$. The storage room temperature of $18 \pm 1{ }^{\circ} \mathrm{C}$ was the lowest possible temperature that could be achieved in the storage room of $5.8 \times 2.8 \times 3.15 \mathrm{~m}^{3}$ with two ACs, one humidifier, and one thermohygrometer.

A unit treatment was ended when the banana fruit reached stage VII (yellow with browning spots; [3] and [4]). The variables used were days of storage (shelf-life), weight loss, ${ }^{\circ}$ Brix, free acidity, firmness, and sweetness level. ${ }^{\circ}$ Brix was analyzed with an Atago N-1E hand refractometer, free acidity was analyzed by a titration with $0.1 \mathrm{~N} \mathrm{NaOH}$ and phenolphthalein as an indicator, and fruit firmness was analyzed with a penetrometer type FHM-5, Takemura Electric Work, Ltd., Japan. Sweetness level was a ${ }^{\circ}$ Brix/acidity ratio. All data were analyzed with ANOVA, and further tested with Least Significantly Difference (LSD) at 5\%.

\section{RESULTS AND DISCUSSION}

Consumers of 'Cavendish' usually judge the quality of 'Cavendish' banana based on its rind color, not on its fruit firmness. On the beginning of this research, its fruit firmness was $11.76 \mathrm{~kg} / \mathrm{cm}^{2}$ (Table 1, footnote) and in 4-7 days storage the fruits soften quickly, reached as low as $0.31 \mathrm{~kg} / \mathrm{cm}^{2}$. The data in Table 1 showed that AVG did not significantly lengthen its fruit shelf-life compared to the control. Its fruit firmness and weight loss were not also affected significantly. A thick rind of banana might play a barrier for anti-ethylene to take into effects on both the ripening rind color stadium development, flesh softening [12] and water loss.

In addition, AVG concentration applied in this postharvest research might be considered very low. However, references on postharvest applications of AVG to 'Cavendish' banana are very lacking. Comparing to the concentrations used by [2] and [13] should be done with cautions because [2] applied it in different stages and with a different chemical, and [13] applied it as a preharvest application, and consequently they used very high concentrations which might be considered uneconomical.

AVG did not also affect other quality parameters, such as soluble solid ( $\left.{ }^{\circ} \mathrm{Brix}\right)$, free acid contents, and its sweetness (Table 2). These three fruit quality parameters were not affected because the observation was terminated at the same stage $[3,4,9$, and 10$]$.

As other fruit coatings generally do, chitosan plays a physical barrier for $\mathrm{O}_{2}$ and $\mathrm{CO}_{2}$ movements, and develops a modified atmosphere around the fruits with less $\mathrm{O}_{2}$ and more $\mathrm{CO}_{2}$. Data in Table 1 showed that the modified atmosphere developed with chitosan lengthened the shelf-life of 'Cavendish' banana fruits by more than two days. A decreased respiration rate of the fruit [14] and [15] might explained the increase. $2.5 \%$ chitosan might also inhibited water loss from the fruits as also reported by [16] - [18]. A significantly higher fruit weight loss than the control as observed in Table 1 was believed as a direct effect of a lengthened fruit shelf-life.

While other fruit qualities, such as soluble solid ( ${ }^{\circ}$ Brix), free acid, and sweetness, were not affected (Table 2), 2.5\% chitosan significantly decreased fruit firmness or accelerated fruit softening (Table 1). Heat deliberated from respiration and trapped inside wrapping might increase temperature inside wrapping, and consequently, accelerated fruit softening [19].

The treatment of low temperature of $18 \pm 1{ }^{\circ} \mathrm{C}$ applied in this experiment significantly lengthened its ripening rind color stadium development of the fruit which was perceived as fruit shelf-life (Table 1). 'Cavendish' banana fruits are usually shipped under a low temperature of $13.33-14.44{ }^{\circ} \mathrm{C}$ (56-58 ${ }^{\circ} \mathrm{F}$; Rachmansyah A. Wardhana, Chairman of R\&D Division of NTF Co. Ltd., personal communication). Therefore, we believed that if a much lower temperature than that of $18 \pm 1$ ${ }^{\circ} \mathrm{C}$ was applied, a much longer fruit shelf-life could be achieved. Low temperature also significantly delayed fruit softening (Table 1) and other fruit chemical qualities such as soluble solid ( ${ }^{\circ}$ Brix), free acid, and sweetness (Table 2), because it might delay respiration rate [20].

A more significant effect of individually applied chitosan was significantly dominated when it was applied in combination with AVG and low storage temperature (Table 1). In fact, a combined application of AVG, chitosan, and low storage temperature increased fruit shelf-life by four days storage compared to the control, but generally they did not affect physical and chemical fruit qualities (Table 2). Again, the reason was due to because the observation was terminated at the same stage of fruit ripening [3], [4], [9], and [10].

\section{CONCLUSION}

The results showed that (1) AVG did not significantly affect fruit shelf-life, physical and chemical fruit qualities such as fruit firmness, weight loss, soluble solid and acid contents, and sweetness; (2) $2.5 \%$ chitosan increased fruit shelf-life, but it accelerated fruit softening and increased fruit weight loss, and did not affect chemical fruit qualities; (3) lower storage temperature significantly lengthened fruit shelf-life and inhibited fruit softening, but did not affect physical and chemical fruit qualities; (4) no interaction was found among the three treatments, in fact, a significant effect of an individual application of chitosan or lower storage temperature dominated the effects of its combinations.

\section{ACKNOWLEDGMENT}

Special thanks are directed to the Directorate General of Higher Education, the Ministry of Education and Culture, the Republic of Indonesia for funding this research through the National Competency Research Grand 2014. Thanks to Nusantara Tropical Farm, Co. Ltd. (NTF, Co. Ltd.), Way Jepara, East Lampung, Indonesia for providing fruit samples and Dr. Agus Karyanto for discussion during preparation of the research report. 
TABLE I

EFFECTS OF AVG, CHITOSAN, AND STORAGE TEMPERATURE ON THE FRUIT SHELF-LIFE, FIRMNESS, AND WEIGHT LOSS OF 'CAVENDISH' BANANA' ${ }^{1}$
TABLE II

EFFECTS OF AVG, CHITOSAN, AND STORAGE TEMPERATURE ON THE FRUIT ${ }^{\circ}$ BRIX, ACIDITY, AND SWEETNESS OF 'CAVENDISH' BANANA

\begin{tabular}{|c|c|c|c|c|c|c|c|}
\hline Treatments & $\begin{array}{c}\text { Shelf-life } \\
\text { (days) }\end{array}$ & $\begin{array}{c}\text { Firmness } \\
\left(\mathbf{k g} / \mathbf{c m}^{2}\right)\end{array}$ & $\begin{array}{c}\text { Weight loss } \\
(\%)\end{array}$ & Treatments & $\begin{array}{l}{ }^{\circ} \text { Brix } \\
(\%)\end{array}$ & $\begin{array}{l}\text { Acidity } \\
\text { (g/100 g) }\end{array}$ & Sweetness $^{2}$ \\
\hline \multicolumn{4}{|l|}{ AVG: } & \multicolumn{4}{|l|}{ AVG: } \\
\hline Control (A0) & $5.08 \mathrm{a}$ & $2.34 \mathrm{a}$ & $11.79 \mathrm{a}$ & Control (A0) & $7.13 \mathrm{a}$ & $0.35 \mathrm{a}$ & $20.24 \mathrm{a}$ \\
\hline AVG (A1) & $5.42 \mathrm{a}$ & $2.49 \mathrm{a}$ & $12.48 \mathrm{a}$ & AVG (A1) & $6.91 \mathrm{a}$ & $0.35 \mathrm{a}$ & $19.60 \mathrm{a}$ \\
\hline \multicolumn{4}{|l|}{ Chitosan: } & \multicolumn{4}{|l|}{ Chitosan: } \\
\hline Control (C0) & $4.08 \mathrm{~b}$ & $4.23 \mathrm{a}$ & $10.85 \mathrm{~b}$ & Control (C0) & $6.98 \mathrm{a}$ & $0.35 \mathrm{a}$ & $19.82 \mathrm{a}$ \\
\hline Chitosan (C1) & $6.42 \mathrm{a}$ & $0.61 \mathrm{~b}$ & $13.43 \mathrm{a}$ & Chitosan (C1) & $7.06 \mathrm{a}$ & $0.35 \mathrm{a}$ & $20.03 \mathrm{a}$ \\
\hline \multicolumn{4}{|l|}{ Temperature: } & \multicolumn{4}{|l|}{ Temperature: } \\
\hline Room (T0) & $4.83 \mathrm{~b}$ & $1.68 \mathrm{~b}$ & $11.29 \mathrm{a}$ & Room (T0) & $6.91 \mathrm{a}$ & $0.35 \mathrm{a}$ & $19.60 \mathrm{a}$ \\
\hline Cool (T1) & $5.67 \mathrm{a}$ & $3.21 \mathrm{a}$ & $12.99 \mathrm{a}$ & Cool (T1) & $7.13 \mathrm{a}$ & $0.35 \mathrm{a}$ & $20.24 \mathrm{a}$ \\
\hline \multicolumn{4}{|l|}{ AVG*Chitosan: } & \multicolumn{4}{|l|}{ AVG*Chitosan: } \\
\hline $\mathrm{A} 0 \mathrm{C} 0$ & $4.00 \mathrm{~b}$ & $3.97 \mathrm{a}$ & $10.55 \mathrm{~b}$ & $\mathrm{~A} 0 \mathrm{C} 0$ & $7.25 \mathrm{a}$ & $0.35 \mathrm{a}$ & $20.57 \mathrm{a}$ \\
\hline $\mathrm{A} 0 \mathrm{C} 1$ & $6.17 \mathrm{a}$ & $0.71 \mathrm{~b}$ & $13.04 \mathrm{ab}$ & $\mathrm{A} 0 \mathrm{C} 1$ & $7.02 \mathrm{a}$ & $0.35 \mathrm{a}$ & $19.91 \mathrm{a}$ \\
\hline $\mathrm{A} 1 \mathrm{C} 0$ & $4.17 \mathrm{~b}$ & $4.53 \mathrm{a}$ & $11.15 \mathrm{ab}$ & $\mathrm{A} 1 \mathrm{C} 0$ & $6.72 \mathrm{a}$ & $0.35 \mathrm{a}$ & $19.06 \mathrm{a}$ \\
\hline $\mathrm{A} 1 \mathrm{C} 1$ & $6.67 \mathrm{a}$ & $0.46 \mathrm{~b}$ & $13.82 \mathrm{a}$ & $\mathrm{A} 1 \mathrm{C} 1$ & $7.10 \mathrm{a}$ & $0.35 \mathrm{a}$ & $20.15 \mathrm{a}$ \\
\hline \multicolumn{4}{|l|}{ AVG*Temp.: } & \multicolumn{4}{|l|}{ AVG*Temp.: } \\
\hline A0T0 & $4.67 \mathrm{a}$ & $1.58 \mathrm{a}$ & $10.70 \mathrm{a}$ & А०Т0 & $6.82 \mathrm{a}$ & $0.35 \mathrm{a}$ & $19.34 \mathrm{a}$ \\
\hline A0T1 & $5.50 \mathrm{a}$ & $3.11 \mathrm{a}$ & $12.88 \mathrm{a}$ & A0T1 & $7.45 \mathrm{a}$ & $0.35 \mathrm{a}$ & $21.14 \mathrm{a}$ \\
\hline A1T0 & $5.00 \mathrm{a}$ & $1.73 \mathrm{a}$ & $11.87 \mathrm{a}$ & A1T0 & $7.00 \mathrm{a}$ & $0.35 \mathrm{a}$ & $19.86 \mathrm{a}$ \\
\hline A1T1 & $5.83 \mathrm{a}$ & $3.31 \mathrm{a}$ & $13.10 \mathrm{a}$ & A1T1 & $6.82 \mathrm{a}$ & $0.35 \mathrm{a}$ & $19.35 \mathrm{a}$ \\
\hline \multicolumn{4}{|l|}{ Chitosan.*Temp.: } & \multicolumn{4}{|l|}{ Chitosan.*Temp.: } \\
\hline С0T0 & $3.83 \mathrm{c}$ & $2.95 \mathrm{~b}$ & $10.08 \mathrm{~b}$ & С0T0 & $6.92 \mathrm{a}$ & $0.35 \mathrm{a}$ & $19.63 \mathrm{a}$ \\
\hline C0T1 & $4.33 \mathrm{c}$ & $5.55 \mathrm{a}$ & $11.62 \mathrm{~b}$ & $\mathrm{C} 0 \mathrm{~T} 1$ & $7.05 \mathrm{a}$ & $0.35 \mathrm{a}$ & $20.01 \mathrm{a}$ \\
\hline C1T0 & $5.83 \mathrm{~b}$ & $0.36 \mathrm{c}$ & $12.49 \mathrm{ab}$ & C1T0 & $6.90 \mathrm{a}$ & $0.35 \mathrm{a}$ & $19.58 \mathrm{a}$ \\
\hline C1T1 & $7.00 \mathrm{a}$ & $0.81 \mathrm{c}$ & $14.37 \mathrm{a}$ & C1T1 & $7.22 \mathrm{a}$ & $0.35 \mathrm{a}$ & $20.48 \mathrm{a}$ \\
\hline \multicolumn{4}{|c|}{ AVG*Chitosan* Temp.: } & \multicolumn{4}{|c|}{ AVG*Chitosan* Temp.: } \\
\hline А०С0Т0 & $3.67 \mathrm{~d}$ & $2.85 \mathrm{bc}$ & $9.37 \mathrm{~b}$ & А०С0T0 & $6.67 \mathrm{bc}$ & $0.35 \mathrm{a}$ & $18.92 \mathrm{bc}$ \\
\hline A0C0T1 & $4.00 \mathrm{~d}$ & $3.05 \mathrm{bc}$ & $10.80 \mathrm{ab}$ & A0C0T1 & $7.17 \mathrm{ab}$ & $0.35 \mathrm{a}$ & $20.33 \mathrm{ab}$ \\
\hline A0C1T0 & $5.67 \mathrm{bc}$ & $0.31 \mathrm{~d}$ & $12.04 \mathrm{ab}$ & A0C1T0 & $6.97 \mathrm{abc}$ & $0.35 \mathrm{a}$ & $19.77 \mathrm{abc}$ \\
\hline $\mathrm{A} 0 \mathrm{C} 1 \mathrm{~T} 1$ & $6.00 \mathrm{ab}$ & $0.41 \mathrm{~d}$ & $12.93 \mathrm{ab}$ & $\mathrm{A} 0 \mathrm{C} 1 \mathrm{~T} 1$ & $6.83 \mathrm{bc}$ & $0.35 \mathrm{a}$ & $19.39 \mathrm{bc}$ \\
\hline A1C0T0 & $4.33 \mathrm{~cd}$ & $5.04 \mathrm{ab}$ & $11.73 \mathrm{ab}$ & A1C0T0 & $7.83 \mathrm{a}$ & $0.35 \mathrm{a}$ & $22.23 \mathrm{a}$ \\
\hline A1C0T1 & $4.33 \mathrm{~cd}$ & $6.06 \mathrm{a}$ & $11.50 \mathrm{ab}$ & $\mathrm{A} 1 \mathrm{C} 0 \mathrm{~T} 1$ & $6.27 \mathrm{c}$ & $0.35 \mathrm{a}$ & $17.79 \mathrm{c}$ \\
\hline A1C1T0 & $6.67 \mathrm{ab}$ & $1.12 \mathrm{dc}$ & $14.03 \mathrm{a}$ & A1C1T0 & $7.07 \mathrm{abc}$ & $0.35 \mathrm{a}$ & $20.05 \mathrm{abc}$ \\
\hline A1C1T1 & $7.33 \mathrm{a}$ & $0.51 \mathrm{~d}$ & $14.70 \mathrm{a}$ & A1C1T1 & $7.37 \mathrm{ab}$ & $0.35 \mathrm{a}$ & $20.91 \mathrm{ab}$ \\
\hline \multicolumn{4}{|c|}{$\begin{array}{l}\text { IValues in the same column of each treatment followed with the same letters } \\
\text { were not significantly different at LSD } 5 \% \text {. Fruit firmness in the day of } \\
\text { treatment (shelf-life } 0 \text { day) was } 11.76 \mathrm{~kg} / \mathrm{cm}^{2} \text {. }\end{array}$} & \multicolumn{4}{|c|}{$\begin{array}{l}{ }^{1} \text { Values in the same column of each treatment followed with the same letters } \\
\text { were not significantly different at LSD } 5 \% \text {. }{ }^{\circ} \mathrm{Brix} \text {, acidity, and sweetness in } \\
\text { the day of treatment (shelf-life } 0 \text { day) were } 8.00 \%, 0.35 \mathrm{~g} / 100 \mathrm{~g} \text {, and } 22.70 \text {, } \\
\text { consecutively; }{ }^{\circ} \mathrm{B} \text { Brix/acidity ratios. }\end{array}$} \\
\hline
\end{tabular}

\section{REFERENCES}

[1] Tong, R.C., 2008 "The Effect of Aminoethoxyvinylglycine (AVG) and 1-methylcyclopropene (1-MCP) on Banana Ripening," Thesis, Fac. Science, Univ. of Johannesburg, 109 pp. Https://ujdigispace.uj.ac.za/bitstream/handle/10210/3265/Tong.pdf?sequ ence $=1$ (26 August 2015).

[2] Toan, N.V., et al., 2009 "Effects of Retain-AVG (aminoethoxyvinylglycine) on the storage time of banana (Musa Cavendish AAA) after harvest," Tap Chi Khoa Hoc Va Cong Nghe, vol. 47(1), pp. 27-33.

[3] Widodo, S.E., Zulferiyenni, Y.C. Ginting, F.H Fazri, and D. Saputra, 2015 "Effects of 1-methylcyclopropene and chitosan on the fruit shelflife and qualities of two different ripening stages of 'Cavendish' banana," J. Food and Nutrition Sci. vol. 3(1-2), pp. 54-59. 
[4] Zulferiyenni, S.E. Widodo, and Y. Simatupang, 2015 "Applications of 1-methylcyclopropene and chitosan lengthened fruit shelf-life and maintained fruit qualities of "Mutiara' guava fruits," J. Food and Nutrition Sci. vol. 3(1-2), pp. 148-151.

[5] Capitani, G, D. L. McCarthy, H. Gutt, M.G. Grutter, and J.F. Kirsch, 2002 "Apple 1-aminocyclopropane-1-carboxylate synthase in complex with the inhibitor L-aminoethoxyvinylglycine: evidence for a ketimine intermediate," J. Biol. Chem., vol. 277(51), pp. 49735-49742. https://doi.org/10.1074/jbc.M208427200

[6] Sisler, E.C, and M. Serek, 1999 "Compounds controlling the ethylene receptor," Botanic. Bull. Acad. Sinica, vol. 40, pp. 1-7.

[7] Workneh, T.S, M. Azene, and S.Z. Tesfay, 2012 "A review on the integrated agrotechnology of papaya fruit," African J. Biotech., vol. 11(85), pp. 15098-15110.

[8] Nasution, I.S, Yusmanizar, and K. Melianda, 2012 "Effects of edible coating, calcium chloride, and plastic wrapping on the qualities of pineapple (Ananas comosus Merr.) minimally processing," J. Teknol. dan Industri Pert. Indonesia, vol. 4(2), pp. 1-6. (Indonesian with English Abstract).

[9] El-Ghaouth, A., R. Ponnampalam, F. Castaigne, and J. Arul, 1992 "Chitosan coating to extend the storage life of tomatoes," J. Hort. Sci., vol. 27(9), pp. 1016-1018.

[10] Widodo, S.E., Zulferiyenni, and R. Arista, 2013 "Coating effect of chitosan and plastic wrapping on the shelf-life and qualities of. 'Mutiara' and 'Crystal' guavas," J. ISSAAS vol. 19(1), pp. 1-7.

[11] Widodo, S.E., Zulferiyenni and D. Novaliana, 2010 " Effects of chitosan on the fruit qualities and shelf-life of 'Muli' and 'Cavendish' bananas," In Proc. $3^{\text {rd }}$ National Seminar on Science and Technology, 18-19 October 2010, University of Lampung. Lampung, Indonesia. (Indonesian with English Abstract).

[12] Jiang, Y.M., and J.R. Fu, 1999 "Biochemical and physiological changes involved in browning of litchi fruit caused by waterloss. J. HortSci. and Biotech., vol. 74(1), pp 43-46. https://doi.org/10.1080/14620316.1999.11511069

[13] Toan, N.V., L.V. Hoang, L.V. Tan, C.D. Thanh, and L.V. Luan, 2011 "Effects of aminoethoxyvinylglycine (AVG) spraying time at preharvest stage to ethylene biosynthesis of Cavendish banana (Musa AAA). J. Agric. Sci. vol. 3(1), pp.206-211. https://doi.org/10.5539/jas.v3n1p206

[14] Widodo, S.E., and Zulferiyenni, 2008 "Chitosan applications in a modified atmosphere packaging technology of lanzone", pp. 278-287 (In Indonesian with English Abstract). In Proc. National Seminar on Food 2008: Increasing Food Security Toward Global Market. Yogyakarta, Indonesia.

[15] Widodo, S.E., Zulferiyenni, and I. Maretha, 2012 "Effect of índole acetic acid (IAA) added into chitosan coating on the fruit qualities and shelf-life of 'Crystal' guava (Psidium guajava L.)," Jurnal Agrotropika, vol. 17(1), pp. 14-18. (Indonesian with English Abstract).

[16] Golomb, A., S. Ben-Yehoshua, and Y. Sarig, 1984 "High-density polyethylene wrap improves wound healing and lengthens shelf-life of mechanically harvested grapefruit," J. Amer. Soc. Hort. Sci., vol. 109(2), pp. 155-159.

[17] Purvis, A. C., 1993 "Effects of films thickness and storage temperature on water loss and internal quality of seal-packaged grapefruit," J. Amer. Soc. Hort. Sci., vol. 108(4), pp 562-566.

[18] Purwoko, B. S., and D. Juniarti, 1998 "Effects of several postharvest treatments and storage temperatures on the quality and shelf-life of 'Cavendish' [Musa (group AAA, subgroup Cavendish)]," Buletin Agronomi, vol. 26(2), pp. 19-28.

[19] Iflah, T., Sutrisno, and T.C. Sunarti, 2012 "Effect of starch-based plastic (bioplastic) packaging on the qualities of tomato and paprika during cool storage," Jurnal Teknologi Industri Pertanian, vol. 22(3), pp. 189-197. (Indonesian with English Abstract).

[20] Paramita, O., 2010 "Effects of bruising on the changes of respiration, ethylene production, and tissues of mango (Mangifera indica L.) cv. 'Gedong Gincu' under different storage temperatures, " Jurnal Kompetensi Teknik, vol. 2(1), pp. 29-38. (Indonesian with English Abstract).

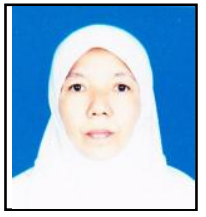

[AVG, $2.5 \%$ chitosan, and lower storage temperature lengthened fruit shelf-life and maintain fruit qualities, but the three were not interacted.] 